\title{
HOSPITALIZATION, ARREST, OR DISCHARGE: IMPORTANT LEGAL AND CLINICAL ISSUES IN THE EMERGENCY EVALUATION OF PERSONS BELIEVED DANGEROUS TO OTHERS*
}

\author{
George A. Huber, $†$ Loren H. Roth, ${ }^{* *}$ \\ Paul S. Appelbaum, $\dagger$ † and Timothy M. Ore***
}

I

\section{INTRODUCTION}

Over the last decade there has been vigorous debate about the propriety of using the mental health system to control those persons who are deemed dangerous to others. ${ }^{1}$ Thomas Szasz's position, albeit extreme, has appealed to those (even within psychiatry) who contend that the criminal justice system, rather than the mental health system, should take primary responsibility for managing such persons. Szasz writes of "the aggressive, paranoid person, who threatens violence. Legally, he should be treated like a person charged with an offense; psychiatrically it would be desirable, of course, if he were not incarcerated in an ordinary jail, but in a prison-hospital, where he could receive both medical and psychiatric attention."'2

This article examines the legal obstacles that hinder implementation of Szasz's suggestion to transfer to the criminal justice system responsibility for control of dangerous persons who are believed to be mentally ill. The issue will be explored from the perspective of the psychiatric emergency room, the point of entry for

Copyright $(1982$ by Law and Contemporary Problems

* The authors wish to express their gratitude to Leslie A. Samolovitch and Linda T. LoCascio for their assistance in the legal and literary research for this article.

$\dagger$ Assistant Director and Legal Counsel, Western Psychiatric Institute and Clinic, University of Pittsburgh.

** Professor of Psychiatry and co-director of the Law and Psychiatry Program, Department of Psychiatry, University of Pittsburgh School of Medicine.

i† Assistant Professor of Psychiatry and Law and co-director of the Law and Psychiatry Program, Department of Psychiatry, University of Pittsburgh School of Medicine and University of Pittsburgh School of Law.

*** Administrative Specialist, Western Psychiatric Institute and Clinic, University of Pittsburgh.

1. See, e.g., T. Szasz, Law, Liberty, and Psychiatry: AN INQUiRy Into The Social Uses of Mental Health Practices (1963); Melick, Steadman \& Cocozza, The Medicalization of Criminal Behavior Among Mental Patients, 20 J. Health \& SOC. BeHaV. 228 (1979); Task Panel, President's Commission on Mental Health, Mental Health and Human Rights: Report of the Task Panel on Legal and Ethical Issues, 20 ARIZ. L. REV. 49 (1978).

2. T. SZASZ, supra note 1 , at 226. 
most violent persons who are funneled into the mental health system. This article will show that present legal and ethical obligations of care givers in the emergency setting all but preclude the possibility of shunting violent persons, once they have been evaluated, out of the system of psychiatric care. Achieving Szasz's goal, which is to some extent endorsed by many psychiatrists who otherwise repudiate his ideas, ${ }^{3}$ would require either a substantial restructuring of legal controls over medical care or a pre-evaluation diversion of dangerous persons to the criminal justice system.

In order to develop this argument, this article will: (1) consider the problem of evaluating potential dangerousness as seen in the psychiatric emergency room, (2) develop a typology of dangerous persons who are seen in that setting, and (3) explore the legal duties that force the mental health system to retain responsibility for controlling dangerous persons once an evaluation has been performed.

II

The Specter of Violence Toward Others in the Emergency ROOM

Although for many years it was argued that the mentally ill are no more dangerous to others than are nonmentally ill persons, lately there has been some reevaluation of this position. As summarized by Steadman, ${ }^{4}$ and Rabkin, ${ }^{5}$ several research studies have recently found that the arrest rate of ex-mental patients is now greater than that of the general population. For example, a 1978 New York study conducted by Steadman, Cocozza and Melick (Steadman study) found that ex-mental patients were about three times more likely than the general population to be arrested for crimes of violence. ${ }^{6}$

The great majority of mentally ill persons do not behave violently towards others, ${ }^{7}$ but a minority of such persons do. The Steadman study found that, following discharge from psychiatric institutions, $1.7 \%$ of patients were arrested for violent crimes over a nineteen-month period. ${ }^{8}$ Some institutions or mental health personnel must assume responsibility for the immediate management of far higher proportions of violent mentally ill persons. ${ }^{9}$ Pepper, in discussing the changing climate in the arena of community treatment, especially problems in treating younger, more difficult patients who are no longer chronically hospitalized in state hospitals, notes that of 100 such patients recently evaluated, fully $10 \%$ had been

3. See, e.g. , Peszke, Is Dangerousness An Issue for Physicians in Emergency Commilment?, 132 AM. J. PsrCHIATRy 825, 826, 828 (1975); Stone, Comment, 132 AM. J. Psychiatry 829, 830 (1975) (comment on Peszke article).

4. Steadman, Critically Reassessing the Accuracy of Public Perceptions of the Dangerousness of the Mentally Ill, 22 J. Health \& Soc. Behav. 310,312 (1981).

5. Rabkin, Criminal Behavior of Discharged Mental Patients: A Critical Appraisal of the Research, 86 PsYCHOLOGICAL BULL. 1, 21 (1979).

6. Steadman, Cocozza \& Melick, Explaining the Increased Arrest Rate Among Mental Patients: The Changing Clientele of Siate Hospitals, 135 AM. J. PsychiaTry 816, 817 (1978).

7. American Psychiatric Ass'n, Task Force Report Number Eight, Clinical Aspects of THE VIOLENT INDIVIDUAL 15 (1974).

8. Steadman, Cocozza \& Melick, supra note 6.

9. Skodol \& Karasu, Emergency Psychiaty and the Assaultive Patient, 135 AM. J. Psychiatry 202 (1978). 
involved with the judicial system because of violent acts. ${ }^{10}$

Two recent articles, one by Monahan, Caldeira and Friedlander (Monahan study) ${ }^{11}$ and one by Bonovitz \& Bonovitz ${ }^{12}$ have shown how police, in the exercise of their discretion, tend to bring to mental hospitals for evaluation and admission persons who have committed violent acts but who, because they are believed to be mentally ill, are judged by the police to be more suitable for admission to a hospital than for confinement in prison. As noted by Bonovitz \& Bonovitz: "In general, police were reluctant to arrest even assaultive mentally ill individuals who were resistant to treatment. On two occasions the officers went to great lengths to talk relatives into seeking involuntary civil commitment rather than pressing criminal charges." 13

Levine, in his review of the records of 100 hospitalized patients, found that among those who had apparently broken the law prior to hospitalization, a substantial minority had committed a variety of serious crimes. ${ }^{14}$ Changing commitment laws, under which commitment is increasingly restricted to persons who are not only mentally ill but who also fit statutory definitions concerning dangerousness to others or self, ${ }^{15}$ also contribute to a climate in which persons deemed clearly dangerous and in need of immediate control as well as mentally ill are brought to psychiatric emergency rooms for evaluation.

10. A Arofile of the New Chronic Patients - Young Adults Who Need Continued Rescue, ROCHE REPORT: Frontiers of Psychiatry, Jan. 1, 1982, at 6 (interview with Pepper).

It is of some interest to note these developments in light of Rabkin's conclusion (on the basis of her review of virtually all relevant research studies so far performed) that:

At the present time there is no evidence that their [discharged mental patients'] mental status as such raises their arrest risk; rather, antisocial behavior and mentally ill behavior apparently coexist, particularly among young, unmarried, unskilled, poor males, especially those belonging to ethnic minorities...

The major factor associated with increases in arrest rates of discharged mental patients in recent years is the increased proportion of mental patients who have arrest histories before their hospitalization.

Rabkin, supra note 5, at 25.

Others, especially Stephen Morse, have also questioned whether there is scientific data that allows us to conclude that criminal behavior committed by the mentally ill is, in fact, invariably or causally related to mental illness. Morse, Cray Behavior, Morals, and Science: An Analysis of Mental Health Law, 51 S. CAL. L. REV. 527, 581-90 (1978).

Steadman and his coworkers have argued that the increased arrest rate of ex-mental patients is due to the changing clientele found in mental hospitals. See Steadman, supra note 6, at 820 . Concerning future risk, the Steadman study found that the ex-mental patients more likely to be arrested following hospitalization were those with arrests prior to hospitalization (the larger the number of previous arrests the greater the risk for subsequent violent arrest), with younger age, and with a diagnosis of drug abuse, alcoholism, or personality disorder. These types of ex-mental patients were more likely to be arrested than those with diagnoses such as schizophrenia, neurosis, or organic brain syndrome, illnesses or impairments of a type that psychiatrists have more traditionally preferred to treat. Id. at 817-19.

11. Monahan, Caldeira \& Friedlander, Police and the Mentally Ill: A Comparison of Committed and Arrested Persons, 2 INT'L. J. LaW \& Psychiatry 509 (1979).

12. Bonovitz \& Bonovitz, Diversion of the Mentally Ill into the Criminal Justice System: The Police Intervention Perspective, 138 AM. J. Psychiatry 973 (1981).

13. Id. at 975 .

14. Levine, Criminal Behavior and Mental Institutionalization, 26 J. Clinical Psychology 279, 282 (1970).

15. See Practice Manual: State Laws Goveming Civil Commitment, 3 MENT. DiSABILrTy L. ReP. 205 (1979); Roth, Mental Health Commitment: The State of the Debale, 1980, 31 Hosp. \& Community Psychiatry 385, $387-88$ (1980). 
Thus Monahan, in his recent comprehensive review of the status of clinical prediction of violent behavior in the mentally ill, has concluded: "The real issue is .. . what sociological and economic factors underlie the administrative and political decision to send more criminals to mental hospitals in the first place."16

The argument of Melick, Steadman, and Cocozza is particularly germane to this paper:

[I] $f$ one is looking for mechanisms entirely within the realm of civil law (to explain the increased number of offenders in New York State mental hospitals) the emergency commitment procedures would appear to be the primary mechanisms for admitting persons to state mental hospitals who could have had criminal charges lodged against them as dangerous, thus shifting their placement from the criminal justice system to the mental health system. ${ }^{17}$

Thus the psychiatric emergency room is faced with the task of evaluating substantial numbers of persons who have demonstrated, threatened, or may have the potential for violent behavior. But not all observers are pleased with the apparent result, namely, that large numbers of violent or potentially violent persons are hospitalized in psychiatric facilities. Monahan, Steadman and his colleagues, Szasz, and even psychiatrists such as Alan Stone ${ }^{18}$ (who argues that some competent, dangerous, mentally ill persons may not be fit subjects for commitment) suggest that certain persons who are admitted to mental hospitals might instead better be handled (and possibly treated) by the criminal justice system. ${ }^{19}$

The greatest reason such violent patients pose problems for hospital staff is that once hospitalized these patients constitute a potential danger to other patients or to the staff itself. If assaultive in the hospital, they may compromise the treatment milieu or the hospital's obligation to protect other patients from harm-an obligation increasingly recognized by the courts as a legal duty of psychiatric hospitals and staff. ${ }^{20}$

The attention of those concerned with these issues is appropriately focused on

16. J. Monahan, The Clinical Prediction of Violent Behavior 81 (1981).

17. 2 Melick, Steadman \& Cocozza, supra note 1, at 234 (emphasis added).

18. Melick, Steadman \& Cocozza, supra note 1, at 234; Monahan, supra note 18, at 81; Stone, The Right to Refuse Treatment: Why Psychiatrises Should and Can Make 1 W Work, 38 ARChives Gen. Psychiatry 358, 361 (1981); T. SzAsz, supra note 1, at 226.

19. Many recent articles in the psychiatric literature discuss the problems that mental health personnel perceive in meeting their increasing burden to manage difficult violent persons who are now evaluated, handled, and treated in mental hospitals. E.g., Edelman, Managing the Violent Mental Patient in a Community Mental Health Center, 29 HosP. \& CoMmuNrTy PSyCHIATRY 460 (1978); Gertz, Training for Prevenlion of Assaultive Behavior in a Psychiatric Setting, 31 Hosp. \& CoMmUNITY PsychiaTry 628 (1980); Hackett, How to Handle the Violent Patient - And Save Your Own Skin, Too, BeHav. Today, Sept. 7, 1981, at 3, 4; Lehmann, Training in Managing Violent Patients, 33 Hosp. \& Community Psychiatry 15 (1982); Lion, Snyder \& Merrill, Underreporting of Assaults on Slaff in a State Hospital, 32 HosP. \& Community PsychIATRY 497 (1981); Liss \& Frances, Court-Mandated Treatment: Dilemmas for Hospital Psychiatry, 132 AM. J. PsYchIATrY 924 (1975); McDonald, Diagnosis May Give Clue to Danger Potential, Psychlatric News Oct. 2, 1981, at 12, 29, 38; Staffs Said to Need Training in Managing Violent Patients, Psychiatric News, Aug. 7, 1981, at 26, 27.

20. See, e.g., Youngberg v. Romeo, 102 S. Ct. 2452, 2458 (1982); Goodman v. Parwatikar, 570 F.2d 801, 804 (8th Cir. 1978); Harper v. Cserr, 544 F.2d 1121, 1123 (1st Cir. 1976); Spence v. Staras, 507 F.2d 554, 557 (7th Cir. 1974); Welsch v. Likins, 373 F. Supp. 487, 502-03 (D. Minn. 1974), affd, 550 F.2d 1122 (8th Cir. 1977); New York State Ass'n for Retarded Children, Inc. v. Rockefeller, 357 F. Supp. 752, 764 (E.D.N.Y. 1973); Appelbaum, Legal Considerations in the Prevention and Treatment of Assaultive Patients, in Assaults in Psychiatric Facilmties (in press). 
the emergency room where dangerous patients are initially evaluated and where the decision is made to admit or to make alternative dispositions. As a result of evaluating potentially dangerous persons, emergency room staff may decide to admit the patient to the hospital (voluntarily or involuntarily) or to outpatient treatment, to return the patient to the police for arrest or for release, to warn others including the police of the patient's dangerousness, or conceivably to do nothing more than to send the person home. After reviewing the variety of clinical presentations that are likely to be observed in the emergency setting, this article will consider the difficulties involved in selecting any option that shifts responsibility from the mental health system to the criminal justice system.

III

\section{A Typology of "DANgerous to Others" Persons Evaluated in THE EMERGENCY ROOM}

Clinicians working in psychiatric emergency rooms are faced with evaluating what we shall categorize as five types of potentially dangerous persons. Although there is some inferential support for these categories from the psychiatric literature, empirical data relevant to making these distinctions in a reliable, valid manner is neither generally available nor of a type allowing firm conclusions. ${ }^{21}$ The distinctions drawn here, however, appear to us to be relevant to making clinically sound and legally supportable dispositions for persons who are considered dangerous to others. This typology draws upon cases from the Western Psychiatric Institute and Clinic of the University of Pittsburgh as well as from the experience of others. ${ }^{22}$

21. See generally J. Monahan, supra note 16; Mesnikoff \& Lauterbach, The Association of Violent Dangerous Behavior with Psychiatric Disorders: A Review of the Research Literature, 3 J. PsychIATRY \& LAW 415,442 (1975); Morse, supra note 10, at 542-60; Prins, Mad or Bad - Thoughts on the Equivocal Relationship Between Mental Disorder and Criminality, 3 INT'L. J. LAW \& PsychiaTry 421 (1980); Uhlig, Hospitalization Experience of Mentally Disturbed and Dismuptive Incarceraled Offenders, 4 J. PsYchLATRY \& LAW 49 (1976).

22. This paper cannot explore in detail the multiplicity of definitional, conceptual, and empirical problems inherent in the task of predicting dangerousness or in classifying persons as imminently dangerous to others. For a discussion of these issues, see generally J. MONAHAN, supro note 16; Shah, Dangerousness: Conceptual, Prediction, and Public Policy Issues, in VIOLENCE AND THE VIOLENT INDIVIDUAL 151 (1981) [hereinafter cited as Shah, Dangerousness]; Shah, Dangerousness: A Paradigm for Exploring Some Issues in Law and Psychialry, 33 AM. Psychologist 224 (1978) [hereinafter cited as Shah, Dangerousness: A Paradigm]. The legal definition of persons as "imminently dangerous to others" for purposes of mental health commitment will vary according to a given state's statutory definition of dangerousness. This paper is specifically concerned with persons deemed likely to be imminently dangerous to others because they have already committed a violent act towards other persons, or because they have threatened such an act and it is believed by mental health personnel that absent mental health treatment (or some other type of handling) such persons will shortly fulfill their threats.

In assessing a person's "dangerousness to others," clinicians should address the probability of occurrence of forthcoming violence and the nature and imminence of the violence towards others. In Pennsylvania, for example, clear and present danger to others is shown by: "[E]stablishing that within the past 30 days the person has inflicted or attempted to inflict serious bodily harm on another and that there is a reasonable probability that such conduct will be repeated." Mental Health Procedures Act, PA. STAT. ANN., tit. 50, $\$ 7301$ (b)(1) (Purdon Supp. 1982-83). The definition of dangerous conduct as provided by the Supreme Court of New Jersey in State $v$. Krol is also helpful: "Dangerous conduct is not identical with criminal conduct. Dangerous conduct involves not merely violation of social norms enforced by criminal sanctions, but significant physical or psychological injury to persons or substantial destruction of property." State v. Krol, 68 N.J. 236, 259, 344 A.2d 289, 301 (1975).

In this article, dangerous behavior is used synonymously with the concept of individual violent behavior manifested towards others. This article also cannot address in detail how psychiatric emergency 


\section{A. Persons Who Are Dangerous to Others Because of Mental Illness}

Despite the unavailability of well-controlled clinical studies on the subject, most mental health clinicians are familiar with patients who manifest violence towards others only in the throes of acute psychiatric illness and thus presumably as a result of that illness. For example, Detre and his coworkers, in delineating a "nosology of violence," describe one group of violent patients that includes patients with paranoid schizophrenia (morbid jealousy), schizophrenic or schizophreniform psychosis, severe manic excitement, and post-partum psychosis. ${ }^{23}$ Such patients behave violently towards others but do so only when they are ill and often in a stereotypic manner. Kermani, in a study of fifty-three hospitalized assaultive patients, delineates a somewhat similar group of patients who reveal no history of sustained violence or of psychopathic-antisocial behavior occurring independently of mental illness. When violent, these patients appear to be reacting in response to delusional thoughts. They give few warning signals before the onset of violent behavior. ${ }^{24}$

Although, as Morse argues, ${ }^{25}$ the above clinical points do not necessarily negate certain logical problems in attributing patient violence directly (or in a unicausal way) to mental illness, the "longitudinal" or life history perspective on these patients renders them, from the perspective of the clinician, reasonable candidates for psychiatric hospitalization. The patient's history clearly reveals that treatment "makes a difference" in the patient's behavior. This is a pragmatic stance, but it is also one based upon the clinician's perception that to pursue alternative dispositions for the patient other than those that involve primarily treat-

room personnel should go about assessing dangerousness, or how to predict that a person will behave in a manner dangerous towards others. This subject has been comprehensively reviewed recently elsewhere. See J. Monahan, supro note 16.

Although it is sometimes argued that the empirical literature has failed to demonstrate the clinician's capacity to predict dangerous behavior (at least over the longer term), AMERICAN PsYCHIATRIC Ass'N, supra note 7, at 23-26, prediction of imminent dangerousness towards others is a prediction that clinicians routinely make. This occurs, for example, when certain patients are hospitalized or when, once hospitalized, these patients are put into seclusion, are removed from seclusion, or are discharged. As Monahan has also noted, there is no empirical study that shows clinicians cannot predict violent behavior towards others over periods of up to several days. Monahan, Prediction Research and the Emergency Commitment of Dangerous Mentally Ill Persons: A Reconsideration, 135 AM. J. Psychiatry 198, 200 (1978). See also Shah, Dangerousness, supra, at 160-61, for a critique of the idea that prediction of dangerousness is impossible under all circumstances.

The consensus of the recent literature on this subject is that in predicting dangerousness for purposes of commitment mental health professionals should not focus only upon the patient's present mental status (e.g., extent of patient agitation, paranoia, delusional ideation, the nature and direction of the patient's threats), but also upon the circumstances and history of the patient's previous or ongoing violent behavior and upon the provocations towards violence that now exist or are likely to exist as a function of the patient's future environment. T. Gutheil \& P. Appelbaum, Clinical Handbook of Psychiatry and THE LAW 58-61 (1982); J. MONAHAN, supra note 16; Roth, Clinical and Legal Considerations in the Therapy of Violence Prone Patients, in 18 Cur Rent Psychiatric Therapies 55 (J. Masserman ed. 1979); Shah, Dangerousness: A Paradigm, supra. Statistical studies indicate that violent behavior is more likely a function of the patient's demographic features, e.g., younger age, lower social class, opiates or alcohol user, lower IQ and educational achievement, residential and employment instability. J. MONAHAN, supra note 16.

23. Detre, Kupfer \& Taub, The Nosology of Violence, in Neural Bases of Violence and AGGRESSION 294,300 (1975).

24. Kermani, Violent Psychiatric Patients: A Study, 35 AM. J. Psychotherapy 215, 221 (1981).

25. Morse, supra note 10 , at 589 . 
ment for illness would be morally wrong and unfair since the patient manifests major mental illness and cannot fully control his behavior.

Because controlling the threat posed by this type of patient involves treating the primary psychiatric condition (treatment usually consisting of antipsychotic or other psychotropic drugs, psychotherapy, and/or social interventions), such patients appear to clinicians to be reasonable candidates for mental hospitalization. This belief is reflected in a number of empirical studies of the emergency admission process which demonstrate that the underlying psychiatric disorder rather than the patient's violent behavior plays the primary role in the decision to admit. Monahan and Warren, for example, found that only the occasional patient (less than $5 \%$ of patients who are committed to mental hospitals) is committed to the hospital solely because he or she is "dangerous to others." 26 This is probably because such patients are often viewed by clinicians as constituting not only a danger to others but also a danger to self (often because their aggression is likely to provoke retaliative assault), or as simultaneously being "gravely disabled." Similarly, Skodol and Karasu found that the physician's decision to hospitalize violent patients was based not on the history of violent behavior per se but, instead, on the basis of a diagnosis of schizophrenia or upon recognition by the clinician that the patient exhibited a major cognitive, perceptual, or behavioral disturbance of a functional, organic, or toxic nature. ${ }^{27}$ The violent act itself failed to distinguish between hospitalized and nonhospitalized patients. Of those patients deemed dangerous to others because of mental illness, the cases considered suitable for emergency hospitalization are those in which the clinician believes the illness to be affecting the patient's rational and executive powers and/or ability to act autonomously.28

\section{Case Example}

A twenty-two year old man with a history of manic-depressive disorder was brought to a psychiatric emergency room for evaluation. He had not been sleeping and was extremely angry and irritable. When his brother insisted that he eat and try to sleep, he forcibly struck his brother with a baseball bat. The patient was uncooperative in the emergency room and refused to consider taking lithium. He was, therefore, involuntarily committed to the hospital on an emergency basis. ${ }^{29}$

\section{B. Persons Who Are Dangerous to Others Because of "Personality Disorders"}

Many persons who are a potential danger to others do not suffer from a psychotic illness but are classified as having "character disorders" or "personality

26. Monahan, Caldeira \& Friedlander, supra note 11, at 516; Warren, Involuntary Commitment for Mental Disorder: The Application of Califomia's Lanterman-Petris-Short Act, 11 LAW \& SOC. R. 629, 645 (1977).

27. Skodol \& Karasu, Toward Hospitalization Criteria for Violent Patients, 21 CoMPREHENSIVE PsychIATRY 162, 163-64 (1980); But see also Appelbaum \& Hamm, Decision to Seet Commitment: Psychialric Decision Making in a Legal Context, 39 ARChIVES Gen. PsychIATRy 447 (1982).

28. M. Peszke, Involuntary Treatment of the Mentaly Ill: The Problem of Autonomy 49-61 (1975); Skodol \& Karasu, supra note 9, at 208.

29. See also Good, Primary Affective Disorder, Aggression, and Criminality, 35 ArChives Gen. Psychiatry 954 (1978). 
disorders."30 Clinicians and legal experts differ over whether such persons should be considered "mentally ill" for legal purposes. ${ }^{31}$ Mental health clinicians may not consider personality-disordered persons as proper subjects for emergency mental hospitalization because their mental disorder is not viewed as a genuine mental illness. Mental health clinicians believe either that such persons can "control" their behavior and therefore ought to suffer its consequences or that such persons are not treatable. These are, however, not always views shared by the legal system.

Part of the characterization problem derives from the variety of ways in which mental illness is defined in state statutes for purposes of involuntary psychiatric hospitalization. Historically, terms such as "mental disorder," "mental disease," "mental illness," "defect," "impairment," "derangement," or even "insanity" have been used. ${ }^{32}$ Not all these legal terms necessarily correspond to medical terms or to concepts with which clinicians are familiar. Moreover, while some states, either in their commitment laws or in their mental health regulations, incorporate medical definitions of mental illness or disorder, others do not. The statute in Iowa, for example, defines mental illness quite broadly to mean "every type of mental disease or mental disorder, except that it does not refer to mental retardation." 33

Other states are less dependent upon medical terms in defining mental illness. In New York the legal definition of mental illness relies, in a typically circular fashion, upon the extent or nature of impairment that the person manifests. Mental illness is statutorily defined as "a mental disease or mental condition which is manifested by a disorder or a disturbance in behavior, feeling, thinking, or judgment to such an extent that the person afflicted requires care, treatment and rehabilitation."34 In Pennsylvania, and in most states, medical and legal concepts are linked. Only persons who are "severely mentally disabled and in need of imme-

30. Personality disorders are defined as inflexible, maladaptive, enduring patterns of perceiving, relating to, and thinking about the environment and oneself, which are exhibited in a wide range of important social and personal contexts and cause either significant impairment in social or occupational functioning or subjective distress. American Psychiatric Ass'n, DSM-III, Dlagnostic and Statistical Manual of Mental. Disorders 305-330 (3d ed. 1980) [hereinafter cited as DSM-III].

31. A well-known case is Williams v. United States, 312 F.2d 862 (D.C. Cir. 1962). One court determined that Mr. Williams was unsuitable for civil commitment because he was not mentally ill (a psychiatrist testified that the patient was not presently psychotic), In re Williams, 157 F. Supp. 871 (D.D.C. 1958), affd, 252 F.2d 629 (D.C. Cir. 1958). Nevertheless, he was later viewed by several psychiatrists as meeting the requirement for criminal insanity because he was believed to have a mental disease (sociopathy) which was productive of his criminal behavior. Williams v. United States, 312 F.2d at 866 . See also Blocker v. United States, 288 F.2d 853, 860 (D.C. Cir. 1961) (Burger, J., concurring). When the Department of Mental Health of the State of Michigan defined mental illness (for purposes of retention in the hospital) as "a substantial disorder of thought, mood, perception, orientation, or memory which significantly impairs judgment, behavior, capacity to recognize reality, or ability to cope with the ordinary demands of life," clinicians in Michigan concluded that this definition encompassed mental illnesses such as psychosis, severe neurosis, or organic conditions but excluded character disorders. Benedek \& Farley, The McQuillan Decision: Civil Rights for the Mentally Ill Offender, Bull. AM. ACAD. Psychiatry \& LaW. 438, 442-43 (1977) (quoting Mich. Dep't of Mental Health Memorandum). Nevertheless, judges and juries when subsequently making decisions about who should be released from the hospital construed character disorders as well as psychotic conditions to be mental illnesses for purposes of retention. Id. at 447.

32. See The Mentally Disabled and the Law 66-71 (S. Brakel \& R. Rock eds. 1971) (table containing statutory definitions of the mentally ill for all 50 states).

33. IOWA CODE ANN. § 229.1(1) (West Supp. 1982-83).

34. N.Y. MENTAL HyG. LaW $\$ 1.03(20)$ (McKinney 1978). 
diate treatment . . . may be made subject to involuntary emergency examination and treatment." 35 Furthermore, "a person is severely mentally disabled when, as a result of mental illness, his capacity to exercise self-control, judgment and discretion in the conduct of his affairs and social relations or to care for his own personal needs is so lessened that he poses a clear and present danger of harm to others or to himself." 36 Mental illness is then further defined in state regulations to be "those disorders listed in the applicable APA [American Psychiatric Association] Diagnostic and Statistical Manual."37 Arizona's statute gives specific attention to this problem. Arizona defines mental disorder to mean "a substantial disorder of the person's emotional processes, thought, cognition, or memory." Specifically excluded from this definition are "[c]haracter and personality disorders characterized by life long and deeply ingrained anti-social behavior patterns."38

The confusion over whether personality disorders constitute mental illnesses for the purpose of commitment is given particular importance by empirical findings that a large percentage of prisoners, presumably including most of those convicted of violent crimes, fall into the personality disorder category and more especially into the classification of "antisocial personality disorder."39 These findings suggest that if a broader definition of mental illness including personality disorders were adopted by emergency room clinicians, a large number of those charged with violent crimes would be eligible to enter the mental health system. That personality disorders are frequently treated as mental illnesses is demonstrated by an Iowa study that reported forty-five percent of diagnoses on commitment papers were "short of psychoses." 40 Monahan, Ruggiero, and Friedlander have recently reported similar findings from California. ${ }^{41}$

\section{Case EXample}

A thirty-four year old drug addict who had a history of armed robbery appeared at the emergency room demanding methadone because of poor sleep. He was in some distress, was angry at others, and was distraught because his wife had recently died of a drug overdose. He was threatening revenge on the drug dealers, and he had a loaded gun. The patient refused voluntary hospitalization. Eventually the emergency room personnel "talked the patient down" and persuaded him to give up his gun to them. When the gun was not returned, the patient became quite angry. After further discussion, however, he agreed to return to the emergency room for reevaluation in a few days.

Several months later the patient, in a drug-intoxicated state and again carrying a loaded weapon, was brought by the police to the hospital for involuntary admission.

35. Pa. Stat. AnN. tit. 50, $\$ 7301$ (a) (Purdon Supp. 1982-83).

36. Id.

37. Admission and Commitment Procedure § 7100.101.3, 9 Pa. Admin. Bull. 317 (1979).

38. ARIz. REv. STAT. ANN. § 36-501(17)(c) (Supp. 1981). Arizona's approach to commitment is thus similar to the ALI approach to specifying criminal insanity. In the well-known "caveat" clause, it is stated "mental disease or defect" does not include "an abnormality manifested only by repeated criminal or otherwise anti-social conduct." Model. Penal Code § 4.01(2) (Proposed Official Draft 1962).

39. S. Guze, Criminality and Psychiatric Disorders 42, 87 (1976).

40. Involuntary Hospitalization of the Mentally III in Iowa: The Failure of the 1975 Legislation, 64 IOWA L. REV. 1284, 1379-80 (1979).

41. Monahan, Ruggiero \& Friedlander, The Stone-Roth Model of Civil Commitment and the California Dangerousness Standard: An Operational Comparison, 39 ARChives Gen. Psychiatry 1267. 


\section{Persons with Coexisting Mental Illness and Dangerousness; Causal Relationship Uncertain}

Mentally ill individuals who have a history of violent behavior may not always manifest that violence as a result of their illness. Psychotic patients, for example, may continue to be violent even after their psychosis is controlled by medication. Empirical findings support this conclusion. Thus in their classification of violent persons, Detre and his group found that the majority of violent individuals had an early onset of violent behavior. This category includes a number of persons who can be diagnosed as "antisocial" or "explosive" personalities. ${ }^{42}$

Boyd and Merskey, ${ }^{43}$ in related work studying the origin of violence in schizophrenic patients, have found that the personal characteristics of aggressive schizophrenic patients resemble those of violence-prone individuals who are not mentally ill more closely than they resemble those of nonaggressive schizophrenic patients. In the experience of Boyd and Merskey, the typical aggressive schizophrenic patient is a young man who has suffered parental brutality, has committed antisocial acts as a child, has frequently abused alcohol, and has used illicit drugs. Kermani also distinguishes a group of mentally ill violent patients, some of whom are psychotic, who are also chronically homicidal and suicidal and whom he labels "violent, depressive personalities" because they have a long history of antisocial behavior and a record of repeated imprisonment for violation of the law. ${ }^{44}$

Moreover, socio-environmental and other situational factors contributing to violence among mentally ill persons are identical to factors that provoke or contribute to violence committed by nonmentally ill persons, e.g., the presence or availability of a lethal weapon. ${ }^{45}$ This reasoning leads to a conclusion that a substantial portion of the "causes" of violent acts committed by mentally ill persons are independent of mental illness, even when patients also manifest major mental illnesses such as schizophrenia.

Followup studies, tracking mentally abnormal offenders after institutional release, including persons who have been found not guilty by reason of insanity (NGRI), support this idea. These studies demonstrate that subsequent failure, recidivism, and rehospitalization in such patients is predicted by two variables: (1) the offender's age at release (the younger the offender, the greater the danger) and (2) the extensiveness of the previous criminal history. ${ }^{46}$ NGRI offenders more nearly resemble other offenders than they do typical psychiatric patients. ${ }^{47}$ Curing the "mad" may not necessarily remove the "bad" or alter the social prognosis. The epidemiological data discussed by Steadman, Rabkin, and Monahan con-

42. Detre, Kupfer \& Taub, supra note 23, at 330.

43. Boyd \& Merskey, quoted in Disease Itself Found Largely Unrelated to Violent Behavior of Schizophrenics, Clinical Psychiatric News, May 1979, at 8 , col. 1 .

44. Kermani, supra note 24 , at 216.

45. AMERICAN Psychiatric Ass'N, supra note 7, at 15-18.

46. Roth, Correctional Psychiatry, in MODERn Legal Medicine, Psychlatry and Forensic SCIENCE $677,700(1980)$.

47. Morrow \& Peterson, Follow-up of Discharged Psychiatric Offenders - "Not Guilly by Reason of Insanity" and "Criminal Sexual Psychopaths", 57 J. CRIM. L. \& POL. Sci. 31, 34 (1966); Quinsey, Pruesse \& Fernley, Oak Ridge Patients: Pre-Release Characteristics and Post-Release Adjustment, 3 J. PsvchiatRy \& LaW 63, 73 (1975). 
cerning recidivism in mental patients ${ }^{48}$ also tend to support the idea that there is a group of patients in which mental illness and a tendency to violent behavior (on the basis of socio-demographic features or other factors) coexist.

The problem for psychiatry in hospitalizing such patients, even when they are mentally ill, is that although mental illness in such patients may be treated, future violence may not necessarily be prevented. This raises some question about the appropriateness of mental hospitalization for these patients as a response to violence, at least to the extent that the need for mental hospitalization is predicated solely or largely upon the expectation that hospitalization will decrease subsequent violent behavior or improve the patient's social adjustment.

On the other hand, since most of these patients carry diagnoses of both psychotic illness and personality disorders and since the latter can be related to their violent acts, problems identical to those discussed in the preceding section arise here. It may be unclear to both clinicians and the legal system whether a genuine mental illness, even if not the patient's primary illness, is causally related to the patient's violent behavior. If this question is answered affirmatively, commitment, as with a pure personality-disordered individual, may be justified on those grounds alone.

An additional problem also arises with this group. In general, the intent of commitment laws is that patients receive psychiatric hospitalization only when their dangerousness is believed to be a direct result of mental illness. ${ }^{49}$ Indeed, many state statutes specifically include the words "as a result of mental illness" when specifying a "dangerousness" requirement for involuntary detention. ${ }^{50}$ However, states do not accomplish this in a clear manner. Patients deemed suitable for hospitalization may be described in a conjunctive manner as those both mentally ill and dangerous. ${ }^{51}$ Despite the literature discussed above, it is of course often not clear to emergency room clinicians whether a patient's dangerousness is a direct "result of mental illness" or is merely conjoined with mental illness. The practical effect of this problem is that, even though patient dangerousness and mental illness may coexist, and not be causally related, such persons frequently are hospitalized rather than arrested or jailed.

\section{Case EXample}

After striking his father while in an angry, suspicious state, a nineteen year old patient diagnosed as having schizo-affective schizophrenia was committed to the psychiatric hospital. He was treated with antipsychotic drugs and rapidly became nonpsychotic. Shortly before discharge and without warning, the patient became angry. He bit a nurse in the breast, leading to his "temporary" transfer to long-term care. Staff viewed the patient's

48. Monahan \& Steadman, Crime and Mental Disorder: An Epidemiological Approach, in CRIME AND JUSTICE: AN ANNuAl Review of Research (in press); Rabkin, supra note 5, at 24-25; Steadman, supra note 4 , at 312 .

49. Postel, Civil Commitment: A Functional Analysis, 38 BroOKlyn L. Rev. 1, 48 (1971).

50. See, e.g., N.D. CeNT. CoDE § 25-03.1-02(11)(Supp. 1981); VA. Code § 37.1-67-3 (Supp. 1982); Wash. Rev. Code. ANn. § 71.05. 240 (West Supp. 1982). See also, Practice Manual: State Laws Coverning Civil Commitment, 3 MENT. DiSABILITY L. REP. 205 (1979) (chart showing statutes of all fifty states).

51. See, e.g., Kan. Stat. AnN. § 59-2902(1) (1976); Wis. Stat. AnN. § 51.20(1)(a) (West Supp. 1982). See also Practice Manual, supra note 50. 
violent behavior as "characterologic" in origin. Several months later when the patient was again brought to the emergency room by the police, there was hesitation and reluctance by the emergency room staff to admit the patient to the hospital. Even though he was again psychotic and had recently been threatening others, the staff maintained that the hospital had "nothing to offer" this patient in the way of treatment.

Unfortunately, the value of psychiatric hospitalization in decreasing future violence when antisocial behavior and mental illness are believed to coexist (even though not necessarily in a causal relationship) is unproven and inadequately studied. ${ }^{52}$

\section{Persons Manifesting Extreme Dangerousness to Others With or Without Mental Illness}

This type of person, who is usually brought to the emergency room by others, causes problems in evaluation somewhat different from those in the three previous categories. The problems for emergency room personnel in making dispositions for these persons are not so much theoretical as pragmatic. Regardless of the presence of mental illness, if the crime of which the person is accused is sufficiently violent or the person is seen as excessively dangerous, then hospital staff are reluctant to hospitalize the person. Hospitalization means that heightened security must be provided to guard the person, transforming the ordinary hospital milieu into a prison; alternatively, the risk of the person perpetrating violence on others once hospitalized is present. Although such persons often already have had legal charges brought against them by the police or others, they are sometimes brought to the hospital without having been formally charged. ${ }^{53}$ Hospital staff may be told to notify the police or others when the patient is "ready for discharge," presumably so that others may then detain the patient. As described in the Monahan study, California commitment procedures include a box on the commitment papers where police may indicate if they wish to be notified when the patient is discharged from emergency hospitalization so that the police can bring charges. ${ }^{54}$

Such extremely dangerous persons are also brought to the hospital for evaluation consequent to making suicidal gestures or threats to the police after having been taken to jail, or sometimes even on the recommendation of defense counselseemingly for purposes of structuring a legal defense. Some persons in this category also bring themselves to the emergency room.

\section{Case Examples}

After being remonstrated by his aunt for drinking too much orange juice, a thirty-eight year old man who had been somewhat schizoid and withdrawn in his adaption suddenly and without warning shot both his aunt and his grandparents, cut them up, put them into

52. Rabkin, supra note 5 , at 26 .

53. If the person is not brought to the emergency room by the police and the authorities have no knowledge of his criminal act, the obligation of the mental health clinician to report the act to the police varies according to jurisdiction. Some states require that physicians report crimes when they have knowledge of them. See, e.g., McIntosh v. Milano, 168 N.J. Super. 466, 486, 403 A.2d 500, 510 (1979); AMERICAN Psychiatric Ass'n, Opinions of the Ethics Committee on the Principles of Medical Ethics with ANnotations Especially Applicable to Psychiatry § 9C, at 24 (1979).

54. Monahan, Caldeira \& Friedlander, supra note 11 , at 513. 
plastic bags, and buried the bags in his apple orchard. The patient confessed this homicide to emergency room staff, also indicating that he was potentially suicidal. Emergency room staff helped the patient to secure an attorney for himself and obtained the patient's agreement that he would immediately "confess" his crime to the police. With the patient's permission, emergency room personnel then contacted the police to tell them about the possible crime so that they could begin an investigation.

A thirty-two year old cocktail waitress murdered her lover. She became distraught and made a serious suicidal attempt in a motel, which led to her admission to a general medical hospital. Once in the hospital she secured access to a weapon and attempted to shoot a second person. Arrangements were made by the patient's defense attorney to have the patient evaluated at the psychiatric hospital for her continuing suicidal potential. The patient was briefly admitted to the hospital, under police guard, while plans were made to transfer her as soon as possible to the county jail where she could be further evaluated by a psychiatrist for possible transfer to a special forensic psychiatric hospital.

\section{E. Persons Who Are Dangerous to Others But Not Mentally Ill}

Many persons who are violent to others are not mentally ill. ${ }^{55}$ This issue, however, is quite complicated because it depends upon what nosology or conceptualization of antisocial personality disorder is given credence. The newer DSM-III formulation of antisocial personality disorder makes resolving this issue particularly problematic. ${ }^{56} D S M-I I I$ relies largely upon a descriptive rather than a psychological (DSM-II) approach to the diagnosis of antisocial personality, thereby unfortunately obscuring differences that may exist among ordinary criminals, persons who commit instrumental violence, and persons who manifest the full constellation of antisocial traits. However, unless one is willing to assert a tautology, viz., that all violent behavior is symptomatic of mental disorder or illness, then clearly there do exist nonmentally ill persons who act violently towards others. ${ }^{57}$

Faced with the prospect of releasing from mental institutions potentially dangerous persons who nevertheless appear free from what has traditionally been regarded as mental illness, some courts have been willing to assert such tautologies. ${ }^{58}$ This issue is under continual discussion in case law relating to whether medical or legal formulations of mental disorder should be of primary importance in making release decisions and other types of decisions concerning potentially violent persons. ${ }^{59}$ While a few courts have ruled that persons evaluated by staff as free from mental illness need not or cannot be civilly committed (even if they have been dangerous to others or are believed likely to commit violent acts), ${ }^{60}$ the impli-

55. J. Monahan, supra note 16 , at 78-79; Mesnikoff \& Lauterbach, supra note 21 , at $417-21$; Roth \& Ervin, Psychialric Care of Federal Prisonets, 128 AM. J. Psychlatry 424, 428 (1971).

56. DSM-III, supro note 30, at 320-21; Uelman, The Psychiatrist, the Sociopath and the Courts: New Lines for an Old Battle, 14 LoY. L.A.L. REV. 1 (1980).

57. See generally, Postel, supra note 49 , at $60-76$.

58. See, e.g., State v. Davee, 558 S.W.2d 335, 339 (Mo. App. 1977); In re Torsney, 47 N.Y.2d 667, 689, 394 N.E.2d 262, 275, 420 N.Y.S.2d 192, 206 (1979) (Wachtler, J., dissenting); Comment, Reforming Insanity Defense Procedures in New York: Balancing Sacietal Protection Against Individual Liberty, 45 ALB. L. REV. 679, 691 n.71 (1981).

59. United States v. Harris, Crim. No. F-1976-79 (D.C. Super. Jan. 30, 1981), summarized in MENT. Disability L. REP. 82 (1981); In re Fleming, 431 A.2d 616, 618 (Me. 1981); Comment, supra note 58.

60. E.g., In re Williams, 157 F. Supp. 871 (D.D.C. 1958); Commonwealth v. Hubert, 494 Pa. 148,430 A.2d 1160 (1981); Cameron v. State, 37 A.D.2d 46, 51-52, 322 N.Y.S.2d 562, 567 (App. Div. 1971), affd, 30 N.Y.2d 596, 282 N.E.2d 118, 331 N.Y.S.2d 30 (1972). 
cation of these cases (and related cases and statutes in the area of criminal insanity and civil commitment) ${ }^{61}$ for the functioning of clinical emergency room mental health personnel has yet to be explored.

However, many violent, nonpsychotic persons, especially those with long criminal records, do appear to clinicians to be logical candidates for the criminal justice system rather than the mental health system, especially when they are brought to the emergency room by the police. As noted above, at least one state, Arizona, excludes character pathology in its definition of mental disorder for purposes of mental health commitment. ${ }^{62}$ Other states exclude drug addiction and alcoholism when these conditions are the sole evidence of mental disorder for purposes of commitment. ${ }^{63}$

\section{IV}

\section{Obstacles to the Transfer of Dangerous Persons to the Criminal Justice System}

It should be evident from the preceding discussion that members of four of the five categories of dangerous persons who are subject to evaluation in the psychiatric emergency room may be appropriate candidates for transfer to the criminal justice system. This is not to suggest that criminal sanctions necessarily ought to be employed against dangerous persons who have committed no criminal acts. Following Szasz, Stone, and others, however, this article assumes that the decision of whether to apply sanctions is more properly made by the criminal justice system than by the mental health system. This article now considers the duties of clinicians in conducting the emergency evaluation and how those duties and other legal issues may impede a transfer of responsibility to the criminal justice system.

\section{A. The Duty to Evaluate, Treat, and/or Refer}

Hospital and emergency room law indicates that clinicians have a duty to evaluate carefully and reasonably the treatment and hospitalization needs of all persons in emergency rooms who are brought to them by others or who come of their own accord. ${ }^{64}$ Neither a government hospital or a voluntary hospital with an emergency room may hold itself out as providing such care and then refuse to provide it, even if the person appears to be unable to pay. ${ }^{65}$ The slightest act of aid or exercise of control over a patient by emergency room staff may create a duty to exercise reasonable care under all facts and circumstances. ${ }^{66}$ All patients who

61. See People v. McQuillan, 392 Mich. 511, 221 N.W.2d 569 (1974); In re Torsney, 47 N.Y.2d 667, 394 N.E.2d 262, 420 N.Y.S.2d 192; see also Benedek \& Farley, supra note 31; Comment, supra note 58.

62. See supre note 38 .

63. See, e.g., Mental Health Procedures Act, Pa. Stat. AnN. tit. 50, $\$ 7102$ (Purdon Supp. 1982).

64. M. Mancini \& A. Gale, Emergency Care and the Law 49-55 (1981); A. Southwick, The Law of Hospital and Health CaRe AdMinistration 182-202 (1978).

65. Wilmington Gen. Hosp. v. Manlove, 54 Del. 15, 174 A.2d 135 (1961); Williams v. Hospital Auth., 119 Ga. App. 626, 168 S.E.2d 336 (1969); Stanturf v. Sipes, 447 S.W.2d 558 (Mo. 1969).

66. Bourgeois v. Dade County, 99 So. $2 d 575$ (Fla. 1957); New Biloxi Hosp., Inc. v. Frazier, 245 Miss. 185, 146 So. 2d 882 (1962); O'Neill v. Montefiore Hospital, 11 A.D.2d 132, 202 N.Y.S.2d 436 (1960); Jones v. City of New York Hosp. for Joint Diseases, 134 N.Y.S.2d 779 (Sup. Ct. 1954), modified, 286 A.D. 825,143 N.Y.S.2d 628 (1955); Methodist Hosp. v. Ball, 50 Tenn. App. 460, 469, 362 S.W.2d 475, 479 (1961). 
present themselves to the emergency room should, therefore, be seen, examined, and treated as their condition requires, preferably under the direction of a licensed physician. ${ }^{67}$

However, the rendering of emergency care does not commit the hospital to admit patients when it is not adequately equipped to give them continuing treatment. ${ }^{68}$ Instead, the hospital is under a positive duty to transfer a patient to another institution along with appropriate medical information if it does not have the appropriate facilities to care properly for the patient and if the circumstances indicate the patient requires transfer. ${ }^{69}$ In general, the requirement for transfer contemplates transfer to another health facility, not transfer to the custody of the police.

As a result of emergency room evaluations, some mental patients will be hospitalized voluntarily; others who meet emergency commitment or detention criteria of state mental health laws but who resist hospitalization will be admitted involuntarily. Still other persons will be determined to be neither foreseeably dangerous to others or to self ${ }^{70}$ nor to require immediate hospitalization for therapeutic reasons. Such persons are usually referred elsewhere to receive later outpatient treatment or may be sent home with no follow-up care whatsoever. Assuming that mental health clinicians make and carefully document their determinations and dispositions in accord with usual professional standards, obtaining consultation where appropriate, they are likely to be judged to have met their duty of care to the patient or to others. ${ }^{71}$

These obligations, which have an ethical as well as a legal basis, are likely to discourage transfer to the criminal justice system for persons who are mentally ill, presumed treatable, and dangerous, especially where the causal link between mental illness and the dangerousness is uncertain.

Although no legal precedents address this point directly, it is arguable that the clinician violates his duty to care for the person he has evaluated by refusing to admit him even though treatment is warranted. Although referral to a more appropriate facility is always an option for the clinician, correctional facilities are notoriously unlikely to fall into this category. The absence of mental health services in most jails and prisons, including the absence of alcohol and other drug detoxification programs, contributes to the emergency room clinician's reluctance to refer dangerous-to-others patients to correctional rather than to medical settings. ${ }^{72}$ Given the dismal history of correctional psychiatry, ${ }^{73}$ it is also unlikely

67. A. SouTHWICK, supra note 64 , at $188,191,194$.

68. Id. at 193.

69. See Carrasco v. Bankoff, 220 Cal. App. 2d 230, 33 Cal. Rptr. 673 (1963).

70. See generally supra note 22 .

71. See B. FurRow, Malpractice in Psychotherapy 23-31 (1980); A. SouthWick, supra note 64, at 194-95. See generally M. MaNcini \& A. GALE, supra note 64.

72. Should the person be so referred, information about his or her condition should be given to the police for transmission to the jail psychiatrist so that the patient's treatment needs may be met in jail or elsewhere. Information concerning the patient's recent history, present medications, and suicide or homicide potential is especially important. Some jurisdictions now have special, mental health units in jails such as the one recently created at the Allegheny County Jail (Pittsburgh, Pennsylvania) as a result of the decision in Inmates of Allegheny County Jail v. Pierce, 612 F.2d 754 (3d Cir. 1979). See also Owens-El v. 
that meaningful or sustained efforts to treat mentally ill persons in jails or prisons will be implemented.

Although the person's dangerous behavior might better be dealt with in the criminal system, the presence of treatable mental illness may lead clinicians to focus on that aspect of the person's condition and to accept the patient into the psychiatric hospital. This is especially likely to occur when the person is desirous of receiving care. Even when the patient does not desire care, the clinician, whose personal bias and legal obligation will be to treat, will unconsciously perceive a causal link between dangerousness and illness that may not be clearly present.

\section{B. The Duty to Protect Third Parties From Dangerous Persons}

The duty to protect others from dangerous persons might be expressed in two ways: an affirmative duty to commit dangerous persons and a negative duty to avoid harm to third parties. These will be considered in turn.

1. An Affirmative Duty to Commit Dangerous Persons. Interestingly, there are very few cases that specifically address the psychiatrist's "duty to commit," and it is debatable whether any such duty exists in the law. Mental health statutes are typically "permissive" rather than mandatory in language; they delineate circumstances in which the mental health clinician may commit patients deemed dangerous to others rather than conditions in which patients shall be committed.

In Fahey v. United States ${ }^{74}$ a New York District Court reviewed the propriety of the failure by the Veterans Administration to commit to an institution a schizophrenic veteran who later murdered a young girl. Upon review of the relevant law the court concluded: "[N]o authority seems to exist whereby any government, Federal or State, or any individual has been held liable for failure to commit. ${ }^{75}$ While Fahey is a twenty-five year old case, it still represents the state of the law on this subject.

Clinicians may sometimes be liable, however, when they make negligent release decisions about mental patients who are already hospitalized and who later harm others. ${ }^{76}$ Liability may also result when hospitals negligently allow to escape

Robinson, 442 F. Supp. 1368, 1381-82 (W.D. Pa. 1978). In Allegheny County, a published guide also gives an overview of the criminal justice and mental health systems, which help clinicians understand patient flow between the two systems. Task Force on Modifications in Forensic Mental Health Services, A Guide to the Criminal Justice and Mental Health Systems for the Mentally Ill Offender/Ex-Offender and Defendant in Allegheny County (available from United Mental Health, Inc., 401 Wood Street, Pittsburgh, PA, 15222). There is, of course, a growing body of literature about how best to provide mental health services in jails and prisons. See, e.g., Petrich, Psychiatric Treatment in Jail: An Experiment in Health-Care Delivery, 27 Hosp. \& Community Psychiatry 413 (1976); Petrich, Metropolitan Jail Psychiatric Clinic: A Year's Experience, $31 \mathrm{~J}$. Clinical Psychiatry 191 (1978); Roth, supra note 46.

In Pennsylvania, mental health regulations specifically permit mental hospitals to share information about patients with prison or correctional authorities (even nonconsensually) when transfer from hospital to prison is contemplated and when clinicians determine that release of such information is essential to ensure continuing adequate care for the patient. Admission and Commitment Procedures, $\S 7100.111 .2(\mathrm{a})(1), 9$ PA. Admin. Bull. 320 (1979).

73. Roth, supra note 46 , at $678-82$.

74. 153 F. Supp. 878 (S.D.N.Y. 1957).

75. Id.' at 886 .

76. See generally Homere v. State, 79 Misc. 2d 972, 361 N.Y.S.2d 820 (Ct. Cl. 1974), affd, 48 A.D.2d 
from the hospital foreseeably dangerous patients who do subsequent harm. ${ }^{77} \mathrm{Nev}$ ertheless, these types of cases do not stand for the proposition that clinicians must initially or uniformly confine all persons who are deemed possibly or foreseeably dangerous. In 1978 a court of appeals in Ohio reviewed the Western Reserve Psychiatric Habilitation Center's failure to readmit a discharged patient who three months after being released shot and killed a person. ${ }^{78}$ While upholding the potential liability of the hospital for release of a patient known (or who should have been known) to be dangerous, the Ohio court rejected "a duty as to readmission similar to the duty of care in discharging" because this "would in effect require the admission of all persons suspected by lay people to be dangerous. The dissimilarities of circumstances and pragmatic effect convinces us that mental hospitals and doctors are not generally under a legal duty to third parties as to decisions not to admit or to readmit a patient."79

Greenberg v. Barbour, ${ }^{80}$ a 1971 case from Pennsylvania sometimes cited as delineating a duty for psychiatric clinicians to admit or to control dangerous mental patients, is ambiguous concerning any so-called "duty to commit." In Greenberg, an admitting room physician failed to examine a patient after it had been determined previously, through telephone calls, that the patient was potentially dangerous and should be admitted. The patient subsequently ran away and injured another. Rather than standing for "a duty to commit," Greenberg suggests that the court was concerned about the potentially negligent manner in which the patient was evaluated after having arrived at the emergency room. The patient was not promptly examined and proper information may not have been transmitted from one physician to another.

One reason a duty for mental health clinicians to commit or admit dangerous mental patients has not arisen is because courts have concluded that psychiatry is an inexact science and that outpatient evaluations made prior to mental health admission do not provide sufficient information upon which to make a reliable determination of the need for hospitalization. "In most instances, the doctor or hospital has only the assessment of lay people as to the condition of the 'patient,' as opposed to the opinions of medical experts after admitting, observing, and examining the patient." 81 Such reasoning, however, may not protect emergency room clinicians who in fact determine their patients to be dangerous but who then fail to take any action to prevent the dangerous behavior from occurring. ${ }^{82}$

Another factor mitigating against the courts' articulation of a clear-cut "duty to commit" is that such a duty placed upon mental health professionals might be contrary to public policy because it would result in excessive numbers of commit-

422, 370 N.Y.S.2d 246 (App. Div. 1975); Annot., 38 A.L.R.3d 699 (1971); Roby, Getting Caught in the "Open Door": Psychiatrists, Patients and Third Parties, 1 MENT. DisABILITY L. REP. 220 (1976).

77. Rum River Lumber Co. v. State, 282 N.W.2d 882, 884 (Minn. 1979).

78. Leverett v. State, 61 Ohio App. 2d 35, 399 N.E.2d 106 (1978).

79. Id. at 41,399 N.E.2d at 110.

80. Greenberg v. Barbour, 322 F. Supp. 745 (E.D. Pa. 1971).

81. Leverett, 61 Ohio App. 2d at 41, 399 N.E.2d at 110.

82. Stone, The Tarasoff Decisions: Suing Psychotherapists to Safeguard Society, 90 HaRV. L. REV. 358,375 (1976). 
ments to mental hospitals. State mental health laws therefore typically include provisions immunizing mental health professionals against potential liability with respect to commitment and even release decisions (assuming the absence of gross negligence), thereby encouraging mental health professionals to exercise discretion in the treatment of the mentally ill. ${ }^{83}$ For example, when in Tarasoff $I I^{84}$ the court articulated a duty for psychotherapists to take steps to protect others from patients whom they knew or should have known to be dangerous (which duty might include making warnings to others or notifying the police), the court also ruled that the defendants had immunity under state law from suit for their failure to confine the dangerous person. ${ }^{85}$

In summary, the absence of a duty to commit implies that if the patient's behavior can be managed through outpatient care (i.e., a reasonable treatment plan can be formulated and initiated while the patient is still in the emergency room), then outpatient treatment may suffice. For some patients, outpatient treatment might even be required in accord with the least restrictive alternative doctrine. ${ }^{86}$ Of note here are Levinson and Ramsey's recent empirical findings that the patient's future environment, including the stress that the environment places on the patient, is the key factor relating to the emergence of subsequent violent behavior. ${ }^{87}$ Assuming the patient is not admitted, the clinician may, therefore, be obligated prior to the patient's release from the hospital to enlist the patient's family, friends, and/or other support system members in supporting the treatment plan. This approach of involving others has the added advantages of sensitizing them to the patient's potential dangerousness and thus helping them to structure the patient's future environment to prevent violence from materializing. Potential victims may be called on the telephone or even summoned directly to the emergency room to engage in therapy with the patient. ${ }^{88}$

2. A Negative Duty to Avoid Harm to Third Parties. Although the courts have failed to articulate a "duty to commit," evolving tort law doctrines have elaborated a negative duty to avoid harm to third parties. A recent Nebraska case, for example, raised the question under the Tarasoff II doctrine of the clinician's duty to confine in order to avoid harm to others. ${ }^{89}$ In Lipari, a veteran, after having been released from a mental institution, purchased a shotgun. Shortly thereafter he resumed

83. Roth, supra note 22 , at 62 .

84. Tarasoff v. Regents of University of California, 17 Cal. 3d 425, 551 P.2d 334, 131 Cal. Rptr. 14 (1976)

85. 17 Cal. 3d at 447, 551 P.2d at 351, 131 Cal. Rptr. at 31 (1976).

86. See generally Hoffman \& Foust, Least Restrictive Treatment of the Mentally IIl: A Dactrine in Search of Its Senses, 14 SAN D. L. Rev. 1100, 1101-22 (1977); Zlotnick, First Do No Harm: Least Restrictive Analysis and the Right of Mental Patients to Refuse Treatment, 83 W. VA. L. REV. 375, 400-05.

87. Levinson \& Ramsay, Dangerousness, Stress, and Mental Health Evaluations, 20 J. HEALTH \& Soc. BEHAV. 178, 184-85 (1979).

88. Roth \& Meisel, Dangerousness, Confidentiality, and the Duty to Wam, 134 AM. J. PsYCHIATRY 508, 51011 (1977); Wexler, Patients, Therapists, and Third Parties: The Victimological Virtues of Tarasoff, 2 INT'L. J. L. \& PSYCHIATRY 1, 17 (1979).

89. Lipari v. Sears, Roebuck \& Co., 497 F. Supp. 185 (D. Neb. 1980). See also a recent case from California where $\$ 282,228$ as awarded to a three year old daughter of a woman who was killed by a veteran who had been evaluated on several occasions at a V.A. hospital. A United States District Court judge noted the physicians' failures to hospitalize the patient as among the reasons why compensation was 
participation in psychiatric day care treatment at a veterans administration hospital. The day care treatment lasted for approximately one month, after which the patient ceased treatment against the advice of his doctors. The following month the patient entered a nightclub and fired a shotgun into a crowded dining room, killing the plaintiff's decedent, Mr. Lipari, and wounding Lipari's wife. The plaintiff alleged that the Veterans Administration was negligent in failing to detain the patient or in failing to initiate civil commitment proceedings against him. The district court ruled that it could not say as "a matter of law that a reasonable therapist would never be required to take precautions other than warnings, or that there is never a duty to attempt to detain a patient." 90

Problems arise in applying Lipari, Tarasoff II, and other cases that have declared a psychiatrist's duty to protect third parties ${ }^{91}$ to the situation of emergency room clinicians whose patients are deemed dangerous to others but not proper candidates for mental hospitalization. In part, this is because there is continuing disagreement about the justification for the courts' rulings in these cases. The courts have relied on different theories to justify why mental health clinicians are obligated to attempt to protect third parties from expectable violent behavior committed by patients.

For example, although Tarasoff II is usually cited for its conclusion that the psychotherapist-patient relationship creates a special exception to the general rule of tort liability that no person has a duty to control the behavior of another, ${ }^{92}$ the Tarasoff II court failed to explain exactly what it was about the doctor-patient relationship that gives rise to the clinician's duty. ${ }^{93}$ To the extent that the clinician's duty to take steps to protect others is predicated upon either the authority or the right that clinicians have to control patients (or upon the fact of control as already exercised in emergency room evaluations), such circumstances may no longer exist when, as a result of evaluation, a patient is found not to meet criteria for mental health commitment because he is not mentally ill and when the patient then terminates the doctor-patient relationship by refusing further care. In this regard, it is notable that the Tarasoff II court specifically declined to rule whether "foreseeability alone," absent a therapist-patient relationship, generates a duty for a therapist to take steps to protect others from the dangerous proclivities of a patient. ${ }^{94}$

An alternative theory that may generate a duty for emergency room clinicians to take steps to prevent dangerous behavior from being manifested by persons deemed not mentally ill or not suitable for mental hospitalization is provided by Professor George Dix:

The basic arguments in favor of imposing a duty to warn [protect] upon therapists can be quite simply stated. Therapists are in a unique position because they can foresee extremely

justified. Jablonski v. United States, No. 79-3504 (C.D. Cal. 1981) (reporter's partial transcript of proceedings) reported in Professional LIABILTTY NewSLETTER, May 1981, at 8, 12.

90. 497 F. Supp. at 193.

91. E.g., McIntosh v. Milano, 168 N.J. Super. 466, 403 A.2d 500 (1979).

92. Restatement (SECOND) OF TORTS $\$ 315$ (1965).

93. Stone, supra note 82 , at 375 n.70.

94. Tarasoff, 17 Cal. 3d at 435, 551 P.2d at 343, 131 Cal. Rptr at 23. 
dangerous conduct on the part of their patients. Consequently the law should provide an incentive for them to anticipate such conduct, and, when it is anticipated, to take reasonable steps to prevent it. ${ }^{95}$

Granting that clinicians have problems in predicting future violence, it can be argued that when mental health clinicians do in fact determine a person to be presently dangerous to others (even if not mentally ill), they ought to act upon such information. The moral duty gives rise to a legal duty. ${ }^{96}$

The court's decision in McIntosh v. Milano is also instructive here. ${ }^{97}$ McIntosh, more clearly than Tarasoff II, predicates the clinician's duty to act not only on the fact of the therapist-patient relationship, but also on the historical duty of the medical profession to protect the public welfare as, for example, in preventing the spread of infectious disease. By similar reasoning, emergency room physicians are in a position to protect the general public from dangerous persons who confess crimes or from persons with "character disorders" who are not suitable for mental health treatment but who are, nevertheless, imminently dangerous to others. Furthermore, although some case law suggests that there is no duty to protect others when the potential victim is unknown, ${ }^{98}$ these precedents may not apply when the clinician has knowledge about whom the patient's victim may be.

It should be evident how these obligations inhibit the transfer of dangerous, nonmentally ill persons, dangerous, character-disordered persons, and dangerous, mentally ill persons with uncertain causal links to the criminal justice system. As the Tarasoff II holding made clear, the obligation to protect third parties may devolve upon the clinician, regardless of intervention or nonintervention by the police. ${ }^{99}$ The initial decision of the police to bring the person to the hospital rather than to jail is, however, often predicated upon police judgment that, for this person, handling by the mental health system is more appropriate than handling by the legal system. ${ }^{100}$ Even when reinvolved, the police are often reluctant to arrest. ${ }^{101}$ Furthermore, in order to avoid embroiling themselves in what in the future may be complicated and time-consuming judicial commitment hearings,

95. Dix, Tarasoff and the Duty to Wam Potential Victims, in LAW and ETHICs in the Practice OF PsYCHIATRY 118, 138 (C. Hofling ed. 1981).

96. Stone, supra note 82 , at 375 .

97. 168 N.J. Super. 466, 403 A.2d 500 (1979).

98. Leedy v. Hartnett, 510 F. Supp. 1125, 1130 (M.D. Pa. 1981), affd, 676 F.2d 686 (3d Cir. 1982); Thompson v. County of Alameda, 27 Cal. 3d 741, 754, 614 P.2d 728, 735, 167 Cal. Rptr. 70,77 (1980).

99. $17 \mathrm{Cal} .3 \mathrm{~d}$ at $431,551 \mathrm{P} .2 \mathrm{~d}$ at $340,131 \mathrm{Cal}$. Rptr. at 20.

100. Monahan, Caldeira \& Friedlander, supra note 11 , at 517

101. The courts are another source of difficulty. There are some reports in the psychiatric literature of therapists bringing charges against mentally ill persons either because this was felt to be a therapeutic maneuver for the patient or because it was believed that, even though mentally ill, the patient was able to control his behavior. See, e.g., Schwarz \& Greenfield, Charging a Patient with Assault of a Nurse on a Psychiatric Unit, 23 Can. Psychiatric A.J. 197 (1978). Courts, however, tend to be skeptical about such a maneuver, especially if the patient is otherwise judged a candidate for mental hospitalization or if the patient is already hospitalized as mentally ill. When an attendant at a mental hospital charged a manic-depressive patient with creating a disturbance at the hospital, the Superior Court of New Jersey declared that:

To convict the involuntary committee of a quasi-criminal offense for displaying the symptoms of his illness while in a place intended to treat that illness, and upon the complaint of one whose duty it is to have the care and custody of such a patient, imposes punishment where none can be either constitutionally or morally justified.

State v. Cummins, 168 N.J. Super. 429, 433, 403 A.2d 67, 69 (1979). 
the police often leave the psychiatric emergency room after the person is brought in for evaluation. The police assume that as a result of the evaluation the patient will either be hospitalized or the clinician will arrange for an alternative disposition. Attempting to reinvolve the police in the patient's care, and sometimes even finding the police to inform them that the patient is not presently ill and does not qualify for mental hospitalization, can be both time consuming and nonproductive. ${ }^{102}$ Thus, uncertain of the response of the police to a request for arrest of the person and aware that often these persons will not have committed chargeable offenses, the clinician has every incentive to maintain control of the dangerous person by hospitalizing him.

There is a further disincentive, to cooperating with the criminal justice system to effectuate a transfer, even when that system may be receptive to the idea. Agreeing to inform the police of the results of an evaluation leaves the clinician potentially liable for untoward occurrences should he fail to follow through with the promised information. ${ }^{103}$ This may be the result of a simple lapse of memory, a concern over the ethical issues at stake, or, most commonly, the transfer of responsibility for the person from one clinician or facility to another. ${ }^{104}$ In the last situation, the failure to communicate the agreement to notify the police to the receiving clinician, as when shifts change, may give rise to a charge of negligence should harm occur. Rather than obligating themselves in this way, clinicians may decide that it is easier simply to avoid contact with the criminal justice system altogether, thus eliminating one source of potential liability.

\section{The Duty to Protect Confidential Communications}

In many states emergency evaluations are included in statutory provisions that guarantee the confidentiality of information gathered in mental health care. ${ }^{105}$ Tort remedies for breach of confidentiality also exist. ${ }^{106}$ In addition, the psychiatric profession and other mental health professions have strong statements in their codes of ethics governing the disclosure of information obtained in confidence. ${ }^{107}$

102. This may be due, in part, to the negligible risk the police run in such cases. While psychotherapists have not always been exonerated from blame when their patients committed violence against others, the police, government agencies, and others in the criminal justice system have, in recent cases, been allowed far greater discretion in their action. See Tarasoff, 17 Cal. 3d at 442, 551 P.2d at 349, $131 \mathrm{Cal}$. Rptr. at 29; Thompson v. County of Alameda, 27 Cal. 3d at 753, 614 P.2d at 734, 167 Cal. Rptr. at 76; Buford v. State, 104 Cal. App. 3d 811,164 Cal. Rptr. 264 (1980).

103. Semler v. Psychiatric Inst., 538 F.2d 121 (4th Cir. 1976), cert. denied, 429 U.S. 827 (1976) (failure to inform a court, as required by court order, of the transfer of a potentially dangerous person from day care to outpatient care); Fair v. United States, 234 F.2d 288 (5th Cir. 1956) (failure to give promised notice to a detective agency protecting a potential victim that the patient was being released); Williams $\mathrm{v}$. United States, 450 F. Supp. 1040 (D.S.D. 1978) (failure of the hospital to give notice as promised to county authorities of the discharge and release of a man with known propensity for violence).

104. See Underwood v. United States, 356 F.2d 92 (5th Cir. 1966) (failure of evaluating psychiatrist to give information to a second psychiatrist about an airman's threat to his wife's life).

105. American Medical Ass'n, Confidentiality of and Patient Access to Medical Records, State HeALTH LEgisLation REPORT, May 1981, at 13-23.

106. Appelbaum, Confidentiality in Psychiatric Treatment, in Psychlatry 1982: The American PsychiATRIC Association ANNuAl Review 328-29 (L. Grinspoon ed. 1982).

107. American Psychological Ass'n, Pinciple 5 - Confidentiality, in Ethical Standards of Psychologists 4 (1977); American Psychiatric Ass'n, The Principles Of Medical Ethics with Annotations Especially Applicable to Psychiatry § 4, at 57 (1981). 
Any effort to transfer to the custody of the police without their consent persons who have been evaluated in an emergency room necessarily involves a massive breach of confidentiality. Clinicians may be uncertain whether they have the legal or ethical right to reveal information about a patient's dangerousness to the police, particularly if no crime has occurred. The above concerns do not mean that clinicians, when they view themselves as justified in so doing, lack support for breaking a person's confidences or initiating steps to prevent others from being harmed. ${ }^{108}$ Already promulgated ethical codes and guidelines of the American Psychiatric Association clearly indicate that it is ethically permissible for psychiatrists to take necessary steps to protect others. ${ }^{109}$ Furthermore, there are recent cases that exonerate physicians from having broken the patient's confidentiality when the patient is determined to be dangerous to himself, others, or others' property. 110

The APA Board of Trustees has also recently recommended the following addition to the Principles of Medical Ethics for Psychiatry: "An ethical psychiatrist may refuse to provide psychiatric treatment to a person who, in the psychiatrist's opinion, cannot be diagnosed as having a mental illness amenable to such treatment."111 Were such a provision of the psychiatrist's ethical code to become final, it would heighten rather than lessen uncertainty for psychiatrists who perform emergency evaluations of potentially dangerous persons, for in rejecting a person for treatment the psychiatrist may still need to decide what to do next about the patient's dangerous proclivities.

Unfortunately, the law is not at all clear on this matter. Courts in two states have rejected the Tarasoff $I I$ doctrine that mental health professionals' obligation to protect third parties outweighs their obligation to protect their patients' confidentiality. ${ }^{112}$ Unable or unwilling to breach confidentiality, or confused about their ability to do so, yet fearful of the consequences that might ensue from releasing dangerous persons outright, clinicians have an incentive to take the only effective measure available to prevent violent acts-hospitalize the dangerous

108. The issue of a clinician's duty to warn potential victims and the resulting problem of breach of confidence will not be addressed in detail here. Several articles discuss this subject. See, e.g., Kjervic, The Psychialric Nurse's Duty to Wam Potential Victims of Homicidal Psychotherapy Outpatients, L. MED. \& HEALTH CARE, Dec. 1981 at 11, 13-14; Knapp \& VandeCreek, Tarasoff: Five Years Later, 13 ProfessionAl PsyCHOLOGY 511 (1982); Roth \& Meisel, supra note 88; Wexler, supra note 88; Beck, When the Patient Threatens Violence: An Empirical Study of Clinical Practice After Tarasoff, 10 Bull. AM. ACAD. PsychiatRy \& LaW 189 (1982).

Our clinical experience suggests that when information about a person's potential dangerousness is shared with others, it is best to do so openly in the presence of and/or with the knowledge of the person who is threatening. Danger may be increased rather than decreased when information about dangerous persons is given to others behind a person's back. Clinicians should, therefore, be honest and straightforward in explaining to persons who are dangerous to others exactly why they intend to share information with others while also obtaining the patient's consent to do this whenever possible. Such an approach communicates to the dangerous person not only the clinician's legitimate concern for the safety of others, but also his concern for the welfare of the dangerous person. The therapeutic task is to help the person recognize that by having divulged information to the clinician or to others, the person has, in effect, already asked for help in controlling his or her violent behavior.

109. American Psychiatric Ass'n, supra note 107, § 4(8) at 6.

110. People v. Hopkins, 44 Cal. App. 3d 669, 674, 119 Cal. Rptr. 61, 64 (1975).

111. AmERICAN PSYChIATRIC ASS'N RePORT, Oct. 9, 1981, at 2.

112. Shaw v. Glickman, 45 Md. App. 718, 727, 415 A.2d 625, 631 (1980); Hopewell v. Adebimpe, 130 Pittsburgh Legal J. 107 (1982) (Pa. C. June 1, 1981). 
person. This is especially true if the person can be considered to have any diagnosable mental disorder.

Even those clinicians who are concerned about the use of the psychiatric care system for the control of dangerous behavior may be reluctant to inform the police about the person's potential dangerousness. For physicians to attempt to rid mental hospitals of social control functions by not admitting to the hospital certain dangerous persons only to attempt to control these persons' dangerous behavior in other ways (e.g., by having these persons arrested) is somewhat paradoxical. The clinician has still used his authority and knowledge not to treat but to control.

Psychiatrists are reluctant to turn emergency rooms into screening clinics wherein dangerous and nontreatable persons are identified for purposes of further processing under the legal system, ${ }^{113}$ possibly violating their privacy rights as citizens. Once more clinicians face a strong temptation to deal with the problem within the mental health system.

\section{Other Legal Problems Impeding Transfer to the Criminal Justice System}

Having completed the emergency evaluation and determined that the person does not meet the statutory criteria for involuntary commitment, the clinician's authority to detain the person further is unclear. Should the person desire to leave, the basis for detention may be a citizen's arrest. In most states private persons (emergency room staff) can perform a citizen's arrest if they have reasonable grounds to believe that a felony has been committed, even though not in their view or presence, or if a misdemeanor has been committed in their view or presence. ${ }^{114}$ "Reasonable grounds" is tested on the basis of what the ordinary, reasonable person would have perceived in the situation. Private citizens are not held to the same strict standards to which the police are held. A citizen may act on information furnished by an informer without testing the informer's credibility and reliability and without corroborating the information by facts within the citizen's personal knowledge. ${ }^{115}$ Of course, there is no affirmative legal duty for emergency room staff to initiate a citizen's arrest.

In the interest of staff and other patient safety, care must be exercised in any attempt to restrain or apprehend the dangerous person. Notifying the police to apprehend the dangerous person may be the only cautious alternative in initiating the citizen's arrest. However, notifying the police without apprehension of the violent person in reality does not serve as a citizen's arrest. Such action merely serves as a notice to the police that there is probable cause that a dangerous person has participated in criminal activity and that a citizen is willing to testify as to why he believes there is probable cause. Citizen's arrest by emergency room staff serves primarily as an instrument to demonstrate to the police the seriousness of a situa-

113. Gaylin, What's an FBI Poster Doing in a Nice Joumal Like That? The AMA, Ethics, and a New Role for the Physicion, Hastings Center REP., April 1972, at 1.

114. Bassiouni, Citizen's arrest: The LaW of Arrest, Search, and Seizure for Private Citizens AND PRIVATe POlice 6-8, 23-26, 60-65, 87-95 (1977) (a review of each state's statutory arrest authority of the private citizen).

115. See id at 36-42. 
tion and the willingness of the people involved to testify during formal proceedings.

The foregoing discussion should make evident the limitations of the citizen's arrest as a means of detaining dangerous persons. Those who have committed no crime and those who admit to misdemeanors such as simple assault but whom the clinician believes dangerous cannot be detained in this manner. Although in most cases the clinician who decides to involve the police may be able to do so without the knowledge of the person under evaluation, if the person discovers that the police have been summoned and attempts to leave, the legal basis for detaining him is not apparent.

\section{$\mathrm{V}$ \\ CONCLUSION}

This article is an initial attempt to catalog and discuss the many legal, clinical, and ethical complexities that confront mental health clinicians who evaluate dangerous-to-others persons to determine whether these persons are reasonable candidates for mental hospitalization. The multiplicity of issues that clinicians must face in making such decisions can sometimes overwhelm the critical faculties of even the most experienced clinicians.

For dangerous mentally ill or nonmentally ill persons to be sent to jails or prisons (instead of being hospitalized), emergency room clinicians must overcome not only difficult problems inherent in the prediction of dangerousness and in assessing causation of violent behavior but also problems in interpreting legal and medical definitions of mental disorder. Clinicians must also face practical issues involved in making transfers to the criminal justice system, problems in avoiding liability while attempting to reduce the probability that others will suffer future harm unnecessarily, and problems related to the legal and ethical principles of confidentiality. In practice these issues of ten become so complicated that once a person is brought to the emergency room and is evaluated by an emergency room clinician as dangerous to others, this person is hospitalized.

Mental hospitalization is the easiest option for clinicians to pursue that will ensure both treatment for the patient and protection for others. This is true even when the clinician finds it personally and professionally distasteful to admit the person to the hospital. Thus as long as family members, police, and even patients themselves continue to come to mental hospitals with complaints relating to a person's violent behavior (whether already accomplished or threatened), such persons will continue to be hospitalized, regardless of the criticism that it is not psychiatry's role to perform a social control function. The only effective means of preventing mental hospitals from fulfilling this role is the attainment of greater societal consensus that potentially dangerous persons should not be brought to the mental hospital for evaluation in the first place. To achieve this, a major educational campaign would have to be mounted to convince both the general public and the police that persons who manifest dangerous, violent behavior towards others that does not result from mental illness truly belong in the criminal justice 
system. Realistically, however, such a campaign is likely neither to occur nor to be effective.

It is unlikely.that there will be many significant reforms in this area of mental health law, as in most other areas of mental health law, until there is better understanding about the fundamental causes of patients' disordered behaviors (including why persons become violent). ${ }^{116}$ The cry to incarcerate rather than to hospitalize dangerous-to-others persons brought to the emergency room is in most instances a cry in the wilderness. 
